Texas A\&M University-San Antonio

Digital Commons @ Texas A\&M University- San Antonio

Criminology and Criminal Justice Faculty

Publications

College of Arts and Sciences

$11-2017$

\title{
How Would You Like to Die? Glossip v. Gross Deals Blow to
} Abolitionists

\author{
Brenda I. Rowe \\ Texas A\&M University-San Antonio, Brenda.Rowe@tamusa.edu
}

Follow this and additional works at: https://digitalcommons.tamusa.edu/crim_faculty

Part of the Criminology and Criminal Justice Commons, and the Legal History Commons

\section{Repository Citation}

Rowe, Brenda I., "How Would You Like to Die? Glossip v. Gross Deals Blow to Abolitionists" (2017). Criminology and Criminal Justice Faculty Publications. 7.

https://digitalcommons.tamusa.edu/crim_faculty/7

This Article is brought to you for free and open access by the College of Arts and Sciences at Digital Commons @ Texas A\&M University- San Antonio. It has been accepted for inclusion in Criminology and Criminal Justice Faculty Publications by an authorized administrator of Digital Commons @ Texas A\&M University- San Antonio. For more information, please contact deirdre.mcdonald@tamusa.edu. 
How Would You Like to Die?: Glossip v. Gross Deals Blow to Abolitionists

Brenda I. Rowe*

Texas A \& M University - San Antonio

Author Note

Brenda I. Rowe, Assistant Professor of Criminology, Department of Humanities and Social Sciences, Texas A\&M University - San Antonio, USA.

The author gratefully acknowledges Craig Hemmens' assistance with editing of the manuscript.

Correspondence concerning this article should be addressed to Brenda I. Rowe, Department of Humanities and Social Sciences, Texas A\&M University - San Antonio, One University Way, San Antonio, TX 78224, USA. (210) 784-2226.

Email: Brenda.Rowe@tamusa.tamus.edu 


\begin{abstract}
After capital punishment opponents' pressure on drug suppliers reduced the lethal injection drug supply, Oklahoma began using midazolam, resulting in botched executions. Condemned inmates sought to stop use of this lethal injection protocol. In Glossip v. Gross, the U.S. Supreme Court found inmates failed to establish such protocols entail a substantial risk of severe pain compared to available alternatives, undermining the supply side attack strategy and leaving inmates facing the possibility of an unnecessarily painful execution. This article places the Glossip decision within the context of method of execution jurisprudence and discusses implications for the ongoing battle over capital punishment.

Keywords: Eighth Amendment, cruel and unusual punishment, execution, capital punishment, lethal injection
\end{abstract}




\section{How Would You Like to Die?: Glossip v. Gross Deals Blow to Abolitionists}

While capital punishment has long been a contentious issue in America, the debate over the death penalty has been reinvigorated recently due to concerns raised by several botched executions during which the lethal injection protocol failed to produce a quick, painless, sanitized execution (Goodwin, 2015). Although these incidents may have taken the public by surprise, they were actually the culmination of a series of events in an ongoing behind-the-scenes battle over capital punishment in America (Stern, 2015). When pressure from capital punishment opponents prompted foreign governments to impose export restrictions and drug manufacturers to refuse to sell to states seeking to use their drugs in executions, corrections departments tasked with carrying out the death penalty faced a shortage of sodium thiopental, the anesthetic long used as part of the lethal injection protocol (Dennis \& Sun, 2014; Sack, 2015; Sanburn, 2013). As a result states began experimenting with alternate drugs for their lethal injection protocols, resulting in executions that did not go smoothly (Dennis \& Sun, 2014; Sack, 2015; Sanburn, 2013).

Oklahoma's first execution using midazolam as part of its lethal injection protocol resulted in a disturbing spectacle during which Clayton Lockett remained conscious, writhed, and experienced what appeared to be a painful, prolonged death (Stern, 2015). After this botched execution, condemned Oklahoma inmates brought a civil rights lawsuit claiming Oklahoma's method of execution violated the Eighth Amendment prohibition on cruel and unusual punishment and sought a preliminary injunction preventing the state from using this lethal injection protocol (Glossip v. Gross, 2015; Stern, 2015). In Glossip v. Gross (2015), a divided U.S. Supreme Court held that the condemned inmates were not entitled to a preliminary injunction because the inmates did not establish that they were likely to succeed on the merits of 
their claim that this lethal injection protocol violated the Eight Amendment, given the inmates' failure to prove that states had an available alternate execution method which would involve substantially less risk of severe pain. The Glossip ruling thus deals a blow to the abolitionist strategy of eliminating the lethal injection drug supply as a means to end executions and leaves condemned inmates to lie in the bed abolitionists have made for them, facing an increased risk of an unnecessarily painful execution because more effective anesthetics are no longer available to the states (Fan, 2015). This article explicates the Court's decision in Glossip v. Gross (2015), places it within the context of recent developments in the administration of executions in the United States and prior relevant death penalty case law, and discusses the implications of this important decision for the ongoing battle over capital punishment in America.

\section{Overview of U.S. Supreme Court Eighth Amendment Capital Punishment Jurisprudence}

Execution methods in the United States have included hangings, firing squads, the electric chair, the gas chamber, and lethal injection (DiStanislao, 2015; Malik \& Holdsworth, 2015). Changes in execution methods over time were ostensibly motivated by a search for more humane methods, but may also have served other purposes such as changing the death penalty's image, making botched executions less visible to the public, reducing public pressure to abolish capital punishment, and reducing public sympathy for the offender (Denno, 2007; Dieter, 2008). Despite numerous challenges to the variety of execution methods, the U.S. Supreme Court has never held that a challenged execution method violates the Eighth Amendment (Dieter, 2008; DiStanislao, 2015).

Traditionally, the Eighth Amendment's prohibition of cruel and unusual punishment was understood to prohibit punishment which involves torture or the infliction of gratuitous pain (Nugent, 1993; Roy, 2002). This reflects a historic approach to interpreting the Eighth 
Amendment, viewing the cruel and unusual punishment clause as proscribing those punishments which were deemed cruel and unusual by the standards prevailing at the time of the adoption of the Bill of Rights (Harding, 1996; Nugent, 1993; Roy, 2002). Early challenges to execution methods had little impact, as these challenges did not succeed and were generally resolved with only minimal delays in executions (Dieter, 2008). The Court has upheld the use of firing squads (Wilkerson v. Utah, 1878), the electric chair (In re Kemmler, 1890), and the repeated use of the electric chair following a botched execution (Louisiana ex rel. Francis v. Resweber, 1947; Nugent, 1993; Roy, 2002).

Weems v. United States (1910) and Trop v. Dulles (1958), cases in which the Court found that noncapital punishments violated the Eighth Amendment due to the punishment being disproportionate to the crime, signaled a shift away from a focus on whether the punishment involved torture or excessive pain towards an interpretation of the Eighth Amendment which takes account of current views of what constitutes cruel and unusual punishment (Harding, 1996; Nugent, 1993; Roy, 2002; Stinneford, 2011). Under this new approach, interpretation of the Eighth Amendment is not restricted to a historic meaning bound by the problems which the founding fathers sought to address (Roy, 2002; Weems v. United States, 1910). Instead, the Eighth Amendment is interpreted in accordance with "evolving standards of decency" (Trop v. Dulles, 1958, p. 101), which is largely ascertained by reference to prevailing practice in terms of objective indicators such as state legislation (Stacy, 2005; Stinneford, 2011).

Weems v. United States (1910) and Trop v. Dulles (1958) are also significant for recognizing that the Eighth Amendment's cruel and unusual punishment clause goes beyond addressing the acceptability of a method of punishment and actually guarantees proportionality in sentence administration (Raeker-Jordan, 2011; Stacy, 2005). The Court has interpreted the 
Eighth Amendment's proportionality requirement as prohibiting the application of the death penalty to certain classes of offenders, including the mentally disabled (Atkins v. Virginia, 2002) and juveniles (Roper v. Simmons, 2005), and certain types of offenses, including rape (Coker $v$. Georgia, 1977; Kennedy v. Louisiana, 2008) and instances of felony murder in which the defendant lacks a culpable mental state (Enmund v. Florida, 1982; Stacy, 2005; Stinneford, 2011).

In addition to the requirements of acceptability of the method of execution and proportionality of the punishment to the crime and the offender's culpability, the Eighth Amendment's cruel and unusual punishment clause requires that the death penalty not be imposed arbitrarily (Furman v. Georgia, 1972; Smith, 2015). After the Court found in Furman v. Georgia (1972) that current death penalty statutes violated the Eighth Amendment prohibition of cruel and unusual punishment by leaving the decision to impose a sentence of death to the jury's unfettered, arbitrary discretion, executions were halted nationwide while states passed new legislation and challenges to those laws worked their way through the courts (Fan, 2015; Malik \& Holdsworth, 2015; Smith, 2015). The Court struck down as unconstitutionally harsh death penalty statutes which imposed a sentence of death for all capital crimes (Roberts v. Louisiana, 1976; Woodson v. North Carolina, 1976) and upheld as constitutional death penalty statutes which established guidelines for juries' decisions regarding whether to sentence a defendant to death (Gregg v. Georgia, 1976; Malik \& Holdsworth, 2015; Radin, 1978).

\section{Lethal Injection Adoption, Challenges, and Baze v. Rees (2008)}

As executions resumed in the wake of Gregg v. Georgia (1976), states began shifting to a new execution method, lethal injection (Malik \& Holdsworth, 2015). This change in execution method represents a medicalization of capital punishment which allows executions to appear 
more humane and makes them less visually disturbing for those viewing the execution (Denno, 2007; Yehuda, 2013). In 1977, Oklahoma was the first state to enact a law authorizing lethal injection as a method of execution, adopting a three-drug protocol hastily devised by a state medical examiner who admittedly lacked expertise in this area (Blythe, 2015; Denno, 2007, 2014). Other states promptly began adopting lethal injection, with many of them copying Oklahoma's three-drug protocol despite the lack of medical studies supporting it (Blythe, 2015; Denno, 2007, 2014). Despite the rapid spread of lethal injection execution methods, some states continued to use older methods of execution (Dieter, 2008). Several challenges to these older methods of execution, while not resulting in the U. S. Supreme Court issuing a ruling on their constitutionality, nevertheless prompted state legislatures to preemptively pass legislation adopting lethal injection as an execution method (Dieter, 2008).

The widely used three-drug lethal injection protocol, first adopted by Oklahoma and copied by other states, consists of an anesthetic used to induce unconsciousness, a paralytic agent which stops respiration, and potassium chloride which causes cardiac arrest (Berger, 2015; Denno, 2007, 2014; Fan, 2015). The three-drug lethal injection protocol has been subject to numerous legal challenges, with a primary concern being that if the anesthetic is not effective, the paralytic agent will mask (but not prevent) the condemned inmate's suffering as the inmate suffocates and endures the burning pain caused by potassium chloride working its way through the inmate's veins (Berger, 2015; Denno, 2007, 2014; Fan, 2015). There are many reasons for concern that the anesthetic used in the three-drug lethal injection protocol may be ineffective, including the particular drug used, the lack of medical training for the personnel administering IV lines or determining level of unconsciousness, the lack of clear procedures, and potential problems with drug quality due to use of unregulated drug sources (Berger, 2015). 
After numerous challenges to the widely used three-drug lethal injection protocol yielded a split in the Courts of Appeal, in 2008 the Supreme Court finally addressed the issue of Eighth Amendment challenges to this execution method (Denno, 2014). In Baze v. Rees (2008), condemned inmates challenged Kentucky's three-drug lethal injection protocol based on a claim that it violated the Eighth Amendment's prohibition of cruel and unusual punishment. The inmates contended that while the anesthetic used in the protocol could render one unable to experience pain if administered correctly, the protocol involved a risk of significant pain when the paralytic agent and cardiac arrest inducing drug are administered if the anesthetic was improperly administered. They argued that the state could instead use less risky procedures such as a single-drug anesthetic-only lethal injection protocol, use of more qualified personnel for carrying out the lethal injection protocol, and use of medical equipment to assess unconsciousness. In Baze, the Court held that Kentucky's three-drug lethal injection protocol, a protocol widely used by other states, did not violate the Eighth Amendment because the condemned inmates failed to prove that their proffered alternative execution procedures significantly reduced a substantial risk of severe pain. In the plurality opinion, the Court reasoned that the Eighth Amendment does not require the avoidance of all risk of pain, which is inevitably associated with any execution method, and declined to adopt an "unnecessary risk" standard, which would involve courts in endless litigation over claims that states are violating the Eighth Amendment by refusing to adopt marginally better alternative execution methods (Baze $v$. Rees, 2008).

Baze v. Rees (2008), far from putting an end to Eighth Amendment challenges to lethal injection, served as a roadmap for such litigation, which proliferated following Baze, prompting some states to switch to one-drug lethal injection protocols, consisting solely of a large dose of 
an anesthetic, in an effort to avoid further litigation (Denno, 2014; DiStanislao, 2015). The lower courts became embroiled in deciding whether the various challenged lethal injection protocols were similar enough to Kentucky's protocol to be upheld as constitutional pursuant to Baze, as well as passing upon the constitutionality of other variants on lethal injection protocols (Grace, 2009; Yehuda, 2013). While adhering to a protocol similar to the one upheld in Baze may have had the lure of potentially being a safe harbor in the litigation storm, states were soon forced to abandon the traditional three-drug lethal injection protocol and begin experimenting with the use of other drugs due to capital punishment opponents' successful campaign to cause drug shortages (“Europe's moral stand," 2014; Fan, 2015; Stern, 2015). This change in lethal injection protocols in turn prompted new litigation challenging the use of untested drugs as posing a risk of pain which constitutes cruel and unusual punishment (Denno, 2014; DiStanislao, 2015; Smith, 2015).

\section{Post-Baze Lethal Injection Drug Shortages and Experimentation}

In recent years, states have encountered shortages of the drugs traditionally used to induce unconsciousness as part of lethal injection protocols, largely due to a combination of Europe's strong stance against capital punishment, the response of both foreign governments and pharmaceutical companies to pressure from opponents of capital punishment, and the desire of health care companies to dissociate themselves from executions ("Europe's moral stand," 2014; Fan, 2015; Stern, 2015). While the European Union's 2005 ban on exports of goods for use in capital punishment or torture was the origin of the chain of events which led to the drug shortage crisis, the drug shortage was acutely felt when the sole domestic producer of sodium thiopental ceased production in 2010 due to a domestic plant contamination issue and was unable to shift production to its plant in Italy due to liability concerns associated with the Italian government's 
demand that the pharmaceutical company assure its drugs would not be used in executions (“Europe's moral stand," 2014).

In response to the drug shortage, states began procuring sodium thiopental from alternate sources abroad ("Europe's moral stand," 2014; Fan, 2015). However, each time the states found a source it was quickly cut off by a human rights non-governmental organization prompting England and the European Union to tighten export restrictions and foreign pharmaceutical companies refusing to sell once they found out the drugs were being used for executions (Stern, 2015). Compounding the states' drug shortage problem, the sodium thiopental which states had managed to obtain from foreign sources before those avenues were cut off were seized by the Drug Enforcement Administration because they were illegally imported from suppliers not approved by the Food and Drug Administration (Stern, 2015).

When states began using pentobarbital for executions due to difficulty in obtaining sodium thiopental, the Denmark-based pharmaceutical company which made the drug in the United States instituted distribution controls which prevented the sale of pentobarbital to prisons in the United States in response to shareholder pressure and unfavorable media coverage prompted by a human rights non-governmental organization drawing media attention to the issue (“Europe's moral stand," 2014; Fan, 2015; Stern, 2015). With this source of pentobarbital no longer available, Oklahoma bought pentobarbital from compounding pharmacies (Stern, 2015). When compounding pharmacies began refusing to sell pentobarbital for use in executions due to public pressure, Oklahoma began using midazolam, a readily-available drug made by many drug companies in the United States, borrowing the idea from Florida and Ohio, which had recently used the drug in executions (Stern, 2015). After botched executions using midazolam occurred in Oklahoma and Arizona, condemned Oklahoma inmates sought review of Oklahoma's lethal 
injection protocol in a civil rights lawsuit which would become known as Glossip v. Gross (Stern, 2015).

\section{Glossip v. Gross}

\section{Facts of Glossip v. Gross}

For years, Oklahoma used the lethal injection protocol which was upheld by the Court in Baze v. Rees (2008). However, Oklahoma was unable to obtain the barbiturate sodium thiopental, the first drug in the lethal injection protocol, when, in response to pressure from death penalty opponents and foreign governments, drug manufacturers refused to sell to parties intending to use their drugs in executions. Oklahoma changed the first drug in the protocol to the barbiturate pentobarbital, but soon the state was also unable to obtain pentobarbital due to drug manufacturers' refusal to sell. Oklahoma then changed the first drug in the protocol to the sedative midazolam, a benzodiazepine.

Oklahoma's first execution using midazolam was botched, as the midazolam failed to keep inmate Clayton Lockett unconscious when the second and third drugs were administered. This resulted in a disturbing spectacle during which the inmate writhed, complained that the drugs were not working, and finally died 40 minutes after the first drug was administered. Following an investigation which faulted the IV line's failure to completely deliver the drugs into the inmate's veins, Oklahoma made changes to its lethal injection protocol aimed at ensuring proper IV insertion and increasing the midazolam dose from 100 to $500 \mathrm{mg}$.

Condemned Oklahoma inmates filed a $\$ 1983$ civil rights action claiming Oklahoma’s current execution method violated the Eighth Amendment. They argued that this execution method created an unacceptable risk of severe pain due to the ineffectiveness of midazolam in preventing pain when the subsequent drugs, a paralytic agent and potassium chloride, were 
administered. Four inmates with fast-approaching execution dates filed a motion for a preliminary injunction prohibiting Oklahoma from using its current lethal injection protocol. Following a hearing, the district court denied the inmates' application for a preliminary injunction because the inmates did not prove midazolam was ineffective in preventing pain. The Court of Appeals for the Tenth Circuit affirmed the district court's denial of a preliminary injunction. Charles Warner, one of the inmates who sought the preliminary injunction, was executed after the Court denied the inmates' application to stay the executions and prior to the Court's grant of certiorari and concomitant stay of the remaining inmates' executions at the state's request.

\section{A Court Divided: Overview of Opinions in Glossip v. Gross}

A unique feature of Glossip v. Gross is the fact that four justices read their opinions from the bench, evidencing a passionately divided Court (Goldfarb, 2015). The decision in Glossip v. Gross was a 5-4 split, with Chief Justice Roberts and Justices Alito, Scalia, Thomas, and Kennedy in the majority and Justices Sotomayor, Ginsburg, Kagan, and Breyer dissenting. In the majority opinion, written by Justice Alito, the Court clarified that an inmate challenging a method of execution as violating the Eight Amendment prohibition of cruel and unusual punishment must prove that the challenged execution method involves a substantial risk of severe pain in comparison to other known, available execution methods. The principal dissent, written by Justice Sotomayor, criticized the Court for changing an absolute prohibition of cruel and unusual punishment into a prohibition which depends on the availability of other less cruel methods for inflicting that punishment. These two opinions squarely address the heart of the claims raised in this case and the majority opinion sets an important precedent which will make 
future Eighth Amendment method of execution claims extremely difficult for condemned inmates to win.

Quite aside from the 5-4 split represented by the majority opinion and the principal dissent, there was also a battle of ideas concerning the constitutionality of the death penalty itself. In addition to the principal dissent, Justice Breyer, joined by Justice Ginsburg, authored another dissent arguing the Court should revisit the constitutionality of the death penalty altogether, regardless of the method used to inflict it. Justice Breyer's dissent elicited scathing responses in the form of two concurrences, authored by Justices Scalia and Thomas, each of whom joined in the other's concurrence, rebuffing this idea as a retread of old abolitionist refrains long since cast aside. While this heated exchange is tangential to the case outcome, it may generate renewed debate about the death penalty's constitutionality and is indicative of the positions Justices Breyer, Ginsburg, and Thomas will take on future capital punishment cases which come before the Court.

\section{Majority Opinion Analysis in Glossip v. Gross}

Justice Alito delivered the majority opinion, in which Chief Justice Roberts and Justices Scalia, Thomas, and Kennedy joined. The Court held that the condemned inmates were not entitled to a preliminary injunction prohibiting Oklahoma from executing them using its current lethal injection protocol because the inmates did not establish that they were likely to succeed on the merits of their claim that this execution method violates the Eight Amendment. In order to succeed on a claim that a method of execution violates the Eighth Amendment, one must prove (a) that the execution method entails a demonstrated risk of severe pain; and (b) that it is a substantial risk in comparison to known, available alternative execution methods. The inmates failed as to both items. The Court affirmed the Tenth Circuit's ruling upholding the district 
court's denial of a preliminary injunction based on two independent grounds. First, the inmates did not identify another known, available execution method which involves a lower risk of pain, as required for claims that an execution method violates the Eighth Amendment in accordance with the controlling precedent, Baze v. Rees (2008). Second, the district court did not commit clear error in finding that the inmates did not prove that the use of a heavy dose of midazolam in Oklahoma's lethal injection protocol involves a substantial risk of severe pain.

Justice Alito noted that although execution methods in the United States have evolved over time as states have sought to adopt methods thought more humane by that era's standards, the Court has never ruled an execution method violates the Eighth Amendment prohibition of cruel and unusual punishment. The Court has upheld as constitutional death by firing squad, electric chair, and the previously widely-used three-drug lethal injection protocol. Justice Alito explained that the Court's decisions upholding various execution methods as constitutional have been based in part on the recognition that there must be some constitutional method of implementing the death penalty since it has been established that the death penalty is constitutional. Thus, since any execution method necessarily involves some risk of pain, the Eighth Amendment cannot require avoiding all risk of pain.

The first reason for the Court's ruling is that the inmates did not prove that using midazolam as part of the lethal injection protocol entails a substantial risk of harm in comparison to other known, available execution methods. The Court rejected the inmates' suggestion that the state could use sodium thiopental or pentobarbital because the district court did not commit clear error in finding those drugs unavailable to the state of Oklahoma. Oklahoma has not been able to obtain sodium thiopental or pentobarbital and the inmates have failed to identify any available drugs that the state could use in lieu of those now unavailable drugs. The Court 
rejected the inmates' argument that they should not be required to identify an acceptable alternative execution method, noting that the controlling precedent, Baze v. Rees (2008), requires an inmate claiming that an execution method violates the Eighth Amendment to plead and prove another known, available execution method involving substantially less risk of severe pain than the challenged execution method.

The second reason for the Court's ruling is that the district court did not commit clear error in finding that the use of a 500-mg dose of midazolam as part of the lethal injection protocol is highly likely to produce an inability to experience pain from the subsequent administration of the other two drugs which are part of Oklahoma's lethal injection protocol. The state's expert gave credible testimony that it was nearly certain that a 500-mg dose of midazolam would render a person sufficiently unconscious so as to not experience pain from the paralytic agent and potassium chloride. In an Eighth Amendment execution method challenge, the inmates bringing the challenge bear the burden of proving the challenged execution method creates a substantial risk of severe pain. The inmates failed to meet this burden of proof, as the inmates' experts admitted that they had no scientific proof contradicting the testimony of the state's expert since there were no scientific studies on the ability of midazolam to prevent a person from experiencing the pain involved with the administration of the second and third drugs. The fact that the use of a small, therapeutic dose of midazolam as the only anesthesia during surgery does not meet the medical standard of care is irrelevant to the issue of whether the much larger dose of midazolam used in Oklahoma's lethal injection protocol is sufficient to meet Eighth Amendment standards for implementing a death sentence. The Court rejected the inmates' argument that midazolam's ceiling effect, or lack of increase in effectiveness as the dosage is increased above a certain level, compromises the district court's finding of the 500-mg 
midazolam dose's efficacy in preventing pain. Because the inmates' experts offered only speculation regarding at what dose a ceiling effect occurs, the inmates failed to establish that the district court's finding was clearly erroneous.

\section{Principal Dissenting Opinion Analysis in Glossip v. Gross}

Justice Sotomayor authored the principal dissenting opinion, in which Justices Ginsburg, Kagan, and Breyer joined. Justice Sotomayor leveled two criticisms at the Court's decision. First, Justice Sotomayor criticized the Court for deferring to the lower court's decision to believe the testimony of the state's sole expert witness, which was illogical, not scientifically supported, and in conflict with the testimony of the inmates' two expert witnesses. Second, Justice Sotomayor criticized the Court's imposition of a new requirement that inmates claiming a method of execution violates the Eighth Amendment must prove that alternative methods of executing them are available to the state.

With regard to the first criticism, Justice Sotomayor faulted the Court for not finding the district court committed clear error in finding that the inmates failed to show that they were likely to prove the state's current lethal injection protocol poses a risk of pain which violates the Constitution. The district court's finding that $500 \mathrm{mg}$ of midazolam can keep someone unconscious when the very painful paralysis-inducing and cardiac arrest-inducing drugs are subsequently administered was based on the state's sole expert witness' testimony, which the district court should not have believed because it was not supported by scientific studies. Furthermore, the inmates proved that the state's lethal injection protocol poses an objectively intolerable risk of severe pain through the testimony of the inmates' two expert witnesses, who stated that there is no dose of midazolam which can maintain unconsciousness when painful stimuli occur and thus the drug is not approved for use as a sole anesthetic during surgery. 
Justice Sotomayor also faulted the Court for creating a new requirement that inmates must identify a known, available execution method posing substantially less risk of pain in order to prevail on a challenge to a state's execution method as constituting cruel and unusual punishment. Not only does the Court cite the Baze v. Rees (2008) plurality opinion as the basis for imposing the requirement even though this position was not taken by a majority of the members of the Baze court, the Court also takes the Baze plurality opinion's requirement out of its specific context and now imposes it on all execution method challenges. In Baze, the plurality opinion stated that when an inmate challenges a state's method of execution based on claims that the current execution method has a higher risk of pain than other procedures which the state could adopt, the inmate must prove that the current execution method poses a demonstrated risk of severe pain and it is a substantial risk in comparison to other known, available execution methods. However, the Baze plurality opinion did not state that any Eighth Amendment execution method challenge requires an analysis of comparative risk.

Justice Sotomayor accused the Court of imposing a new rule which would allow the state to use barbaric, torturous execution methods, such as burning the condemned inmate alive, if an inmate challenging such execution methods fails to identify another known, available execution method which poses substantially less risk of pain. However, the Eighth Amendment prohibits cruel and unusual punishment, not just punishments which are cruel and unusual in comparison to other available execution methods, and if the only available execution method is cruel and unusual, then the state cannot constitutionally implement a death sentence. Rather than punishing inmates for drug shortages they did not cause by imposing additional requirements on their Eighth Amendment challenges to execution methods, the Court should be reviewing execution methods more closely since states are adapting to drug shortages by experimenting on 
inmates with hastily adopted new protocols involving untested drugs, thus increasing the chances that execution methods will result in a substantial risk of severe pain.

\section{Dissent Relating to Per Se Constitutionality in Glossip v. Gross}

Justice Breyer authored an additional dissenting opinion, joined by Justice Ginsburg, in which he urged the Court to request briefing on the issue of the constitutionality of capital punishment and recounted the reasons he believes it is very likely capital punishment violates the Eighth Amendment prohibition of cruel and unusual punishment. Justice Breyer said it is time to reevaluate the death penalty's constitutionality according to current societal standards because during the nearly four decades which have passed since Gregg v. Georgia (1976), it has become evident that the procedures developed by the states cannot guarantee the reliable, non-arbitrary application of capital punishment, as evidenced by empirical studies and experience. Justice Breyer opined that capital punishment is both cruel, due to its unreliability and arbitrariness along with excessive delays which undermine the death penalty's purpose, and unusual, as relatively few states now actually execute inmates.

Justice Breyer cited as evidence of capital punishment's unreliability the exoneration of wrongfully convicted death row inmates and researchers' discovery of compelling evidence of incidents of the execution of innocent persons, some of whom have been posthumously pardoned. Justice Breyer noted that it is troubling that those convicted of capital offenses are far more likely to be exonerated than those convicted of other crimes. He observed that this may indicate a greater likelihood of wrongful conviction owing in part to public pressure to obtain convictions for gruesome crimes, errors in forensic evidence analysis, and the use of deathqualified jurors, which research shows results in a jury biased towards conviction. 
Justice Breyer cited as evidence of capital punishment's arbitrariness the many empirical studies which have found that relevant factors such as egregiousness of the crime do not influence who receives the death penalty while irrelevant factors, such as the victim's race, the defendant's or victim's gender, and geographical location, do influence who receives the death penalty. Both these empirical studies' findings and Justice Breyer's own experience on the bench observing irrational discrepancies in who receives the death penalty, with some receiving the death penalty while others who committed far more egregious crimes do not, demonstrate that capital punishment is imposed in a capricious, arbitrary manner rather than being reserved for the worst offenders.

Justice Breyer opined that the excessive delay in executing condemned inmates both aggravates the cruelty of capital punishment and so undermines its purported purposes of deterrence and retribution that it renders capital punishment the infliction of pain without any legitimate purpose, thus making the death penalty unconstitutional. Excessive delays in execution constitute cruelty because death row inmates are typically held in solitary confinement, which is harmful to mental health, and the dehumanizing effects of such conditions are amplified by the uncertainty under which the condemned inmates must live with regard to whether and when they will actually be executed. Furthermore, excessive delays, combined with the rarity of an inmate actually being executed, undermine capital punishment's ability to deter or satisfy the community's desire for retribution. Such delays are inevitable given the need to ensure reliability and fairness in cases which have such high stakes. Justice Breyer stated that our inability to have both a death penalty which serves a legitimate purpose and a system which seeks to ensure fairness and reliability in the application of capital punishment is strong evidence 
that capital punishment violates the Eight Amendment's prohibition of cruel and unusual punishment.

Finally, Justice Breyer argued that the rarity of death sentences in the United States makes capital punishment an unusual punishment, thus contravening the Eighth Amendment prohibition of cruel and unusual punishment. Justice Breyer cited the rapid decline in both the number of people sentenced to death and the number of people actually executed in the United States for the past 15 years, the fact that $60 \%$ of the states either have abolished the death penalty or have not executed anyone for the past 8 years, three states' disproportionate contribution of $80 \%$ of the executions occurring in the United States during 2014, and the geographic concentration of executions in relatively few counties as evidence that capital punishment is now unusual. For all of these reasons, Justice Breyer concludes that it is very likely capital punishment violates the Eighth Amendment prohibition of cruel and unusual punishment and urges the Court to request briefing on the issue of whether capital punishment is unconstitutional per se.

\section{Concurrences Relating to Per Se Constitutionality in Glossip v. Gross}

Justice Scalia authored a concurring opinion, joined by Justice Thomas, in which he responded to Justice Breyer's call for the Court to abolish capital punishment. Justice Scalia noted that the Court has never declared that the death penalty is unconstitutional, ostensibly because the text of the Constitution specifically references capital crimes. Justice Scalia criticized Justice Breyer for attempting to change the meanings of the Eight Amendment terms cruel and unusual, and for advancing a meaningless, contradictory argument.

Justice Scalia attacked Justice Breyer's argument that the death penalty is cruel because it is unreliable as nonsense, noting that it is not the punishment that is unreliable, but the 
convictions. Justice Scalia contended that changing the punishment for terrible crimes will not reduce public pressure to convict, which emanates from the crime's terrible nature rather than from the potential punishment, and that an innocent defendant actually has better chances on appeal when sentenced to death rather than life due to receiving help from the abolitionists in the form of an unlimited supply of legal representation and judicial favoritism.

Justice Scalia refuted Justice Breyer's argument that the death penalty is cruel because it is arbitrary, noting that the study on which Justice Breyer relies presumptuously attempts to measure the egregiousness of crimes when these are moral judgments which must be made in context by juries alongside consideration of all the considerations relevant to punishment. Variation in juries' judgments from one case to another is inherent in the use of juries and the fact that some juries do not impose the greatest authorized punishment does not make capital punishment cruel.

Finally, in response to Justice Breyer's argument that the death penalty is cruel because of the lengthy delays involved, Justice Scalia observed that life without parole is no shorter a period of confinement and that objections to the conditions of solitary confinement can be ameliorated by altering conditions of confinement rather than resorting to abolition. Justice Breyer's contention that delays deprive the death penalty of serving any legitimate purpose neglects to take into account the incapacitation purpose served by the death penalty, as evidenced by the fact that one of the inmates in the present case committed murder while in prison, and rests on Justice Breyer's assessment that a life sentence is retributive enough when such assessments are not within the judiciary's purview. Regarding Justice Breyer's conjecture that it is unlikely capital punishment has a significant deterrent effect, Justice Scalia noted that a number of studies find a deterrent effect and accused Justice Breyer of being insensitive to the 
needs of those who live in neighborhoods plagued by violence by seeking to override the citizens' determination of the value of the incremental deterrence provided by the death penalty.

Justice Scalia accused Justice Breyer, in arguing that associated delays make the death penalty cruel and thus require abolition, of taking advantage of delays which the Court created, with Justice Breyer leading the way down this ill-advised path, by producing a complicated maze of restrictions on the death penalty which conform to society's evolving standards of decency as ascertained by the Court in its post-Trop v. Dulles (1958) jurisprudence. Justice Scalia noted also that Justice Breyer relies on the trend of states forsaking use of the death penalty in his assessment that the death penalty has become an unusual punishment when this trend has been prompted by the costs created by this line of jurisprudence. If the Court were to revisit the constitutionality of capital punishment as Justice Breyer urged, Justice Scalia would call for briefing of whether Trop and its progeny should be overruled, as Trop has damaged federalism, rests on the faulty assumption that the Court is well equipped to ascertain societal standards of decency, and emboldens a minority of the justices to attempt to impose their own standards of decency on citizens who have repeatedly voted in favor of capital punishment.

Justice Thomas also authored a concurring opinion, joined by Justice Scalia, in which he responded to Justice Breyer's claim that the death penalty is not being reserved for the most egregious offenses. Justice Thomas criticized Justice Breyer's reliance on abolitionist studies, which find that death sentences are not correlated with the crimes' egregiousness and are correlated with geographic location of the crime, as evidencing disrespect for the Constitution's mandate that a jury of the defendant's peers is responsible for making the decision of whether to impose the death penalty. The study on which Justice Breyer mainly relied was based on law students' moral judgments of level of egregiousness of hypothetical murders based on written 
synopses, but the Constitution places such moral judgments in the hands of jurors from the local community who have observed a full trial, not elites who sit in law school and read hypothetical factual scenarios. Furthermore, it is unsurprising that the study finds that geographic location of the crime explains the imposition of death sentences better than law students' egregiousness scores do, as the Constitution's placement of punishment decisions in the hands of local juries appears to intentionally introduce geographic location as a factor in sentencing, leaving moral judgments regarding punishment in the hands of the defendants' local peers. Thus, the correlation between the geographic location in which the crime was committed and death sentences cannot be considered an indicator of arbitrariness.

Regardless, Justice Thomas asserts the study's findings are unreliable, and thus constitute an unsuitable basis for declaring capital punishment unconstitutional, because this study relies on a series of moral judgments in which depravity is arbitrarily quantified by assigning points reflecting how much a victim's life is worth based on stereotypical assessments. After expressing outrage over the cold mathematical calculation of which victims lives are worth more than others, Justice Thomas proceeded to recount the gruesome details of numerous capital cases which demonstrate that there is not a problem of capital cases being insufficiently egregious to justify capital punishment. Justice Thomas then argued that the Court has been attempting to undemocratically abolish the death penalty by creating a series of unfounded Eighth Amendment claims in a line of cases which have exempted the mentally challenged, juveniles, and rapists from capital punishment, allowing the perpetrators of some of the most egregious crimes to escape the death sentences imposed by juries. Justice Thomas opined that if Justice Breyer is uncomfortable with disparate outcomes, the Court should stop inventing Eighth Amendment claims which allow some capital defendants to escape the jury's moral judgment that their crimes 
are so egregious that they warrant the ultimate penalty while others are not granted such a reprieve.

\section{Implications}

An immediate implication of the Court's decision in Glossip is that states can use the specific lethal injection protocol upheld in this case, which includes reliance on midazolam alone to induce unconsciousness, with assurance that it does not violate the Eighth Amendment. States which had been holding off on conducting executions due to drug shortages combined with uncertainty about litigation risks inherent in substituting midazolam in their lethal injection protocols have already resumed conducting executions (Berman, 2017; Goldberg, 2015).

Just as Baze failed to put an end to the litigation challenging lethal injection (Denno, 2014), Glossip likely has not put the issue to rest once and for all, as any lethal injection protocol which varies from the one upheld in Glossip will still be subject to challenge. Some states may try to adhere strictly to the lethal injection protocol upheld in Glossip in order to avoid further litigation. However, just as the strategy of adhering to the lethal injection protocol upheld in Baze became unfeasible due to drug shortages (Denno, 2014), over time states may encounter practical obstacles to continued use of the Glossip-approved lethal injection protocol which necessitate variation.

Since states are continuing to face shortages of the drugs traditionally used in lethal injection protocols, the Court's decision in Glossip will likely embolden states to engage in more widespread experimentation with changing lethal injection protocols to include the use of drugs not traditionally or widely used in lethal injection protocols and off-label use of drugs (use of drugs for purposes for which they have not been approved by the Food and Drug Administration; Goldberg, 2015). Such experimentation may well result in more botched executions, which have 
the potential to sway public opinion in favor of abolition (Goldberg, 2015). This

experimentation is also likely to spawn continued litigation challenging states' lethal injection procedures. In fact, in the wake of the Glossip ruling, an attorney who represented one of the inmates in that case vowed continued legal action challenging states' lethal injection methods (Berman, 2015).

The Court's decision in Glossip will make it more difficult for condemned inmates bringing Eighth Amendment method of execution claims to prevail. The Court has now made it abundantly clear that the inmates must prove that states have an available alternative execution method which involves substantially less risk of severe pain. Even if condemned inmates challenging another lethal injection protocol prove it involves a demonstrated risk of severe pain, the drug shortages faced by the states, ironically largely due to pressure from death penalty opponents (“Europe's moral stand," 2014; Fan, 2015), may make it difficult for the inmates to prove the state has an available alternative execution method which would present substantially less risk.

Unfortunately, the success of capital punishment opponents' campaign to dry up the supply of anesthetics previously commonly used in lethal injection protocols has resulted in states experimenting with lethal injection protocols which use drugs of more questionable value in preventing condemned inmates from experiencing pain (DiStanislao, 2015; "Europe's moral stand," 2014; Fan, 2015). The Court's holding in Glossip undermines the value of this strategy of trying to end executions by making lethal injection drugs unobtainable. However, given Europe's strong stance against facilitating capital punishment as well as the public relations and ethical issues which drive pharmaceutical companies' aversion to having their drugs associated with executions ("Europe's moral stand," 2014), it is unlikely that the trend of increasing scarcity 
of effective anesthetics will be reversed. By requiring condemned inmates challenging an execution method as cruel and unusual to prove there is an available alternative execution method which involves substantially less risk of severe pain, the Court leaves condemned inmates to lie in the bed abolitionists have made for them. The abolitionist strategy of undermining the supply of lethal injection drugs, combined with the Court's decision in Glossip, increases condemned inmates' risk of an unnecessarily painful execution (Fan, 2015).

Finally, Justice Breyer's dissent is likely to renew debate about the constitutionality of the death penalty itself. This debate may raise consciousness about the problems associated with capital punishment, which may in turn increase the ranks of death penalty opponents or at least further sway the opinion of those who have supported the death penalty but have begun to have misgivings about it due to public awareness of wrongful convictions and botched executions. While Justice Breyer's dissent likely will be heartening to death penalty opponents, it is unlikely that the Court will declare capital punishment unconstitutional per se absent a change in the Court's composition, as only two justices endorsed this position. However, it is quite likely that the Court will continue to be active in deciding issues surrounding challenges to various aspects of capital punishment and the ideological divide between Justices Breyer and Ginsburg and Justice Thomas is likely to continue to shape the coalitions and discourse on the Court's capital punishment cases. 


\section{References}

Atkins v. Virginia, 536 U.S. 304 (2002).

Baze v. Rees, 553 U.S. 35 (2008).

Berger, E. (2015). The executioners' dilemmas. University of Richmond Law Review, 49(3), 731762. Retrieved from http://lawreview.richmond.edu/

Berman, M. (2015, June 29). Oklahoma says it will resume executions after Supreme Court's ruling on lethal injection. The Washington Post. Retrieved from https://www.washingtonpost.com/

Berman, M. (2017, April 21). Arkansas carries out first execution since 2005 after Supreme Court denies stay requests. The Washington Post. Retrieved from https://www.washingtonpost.com/

Blythe, H. (2015). "Laboratories of democracy" or "machinery of death?" The story of lethal injection secrecy and a call to the Supreme Court for intervention. Case Western Reserve Law Review, 65(4), 1269-1289. Retrieved from http://law.case.edu/journals/lawreview/Home.aspx

Coker v. Georgia, 433 U.S. 584 (1977).

Dennis, B., \& Sun, L. H. (2014, April 30). For more states, execution means improvisation as drug supplies dwindle. The Washington Post. Retrieved from https://www.washingtonpost.com/

Denno, D. W. (2007). The lethal injection quandary: How medicine has dismantled the death penalty. Fordham Law Review, 76(1), 49-128. Retrieved from http://fordhamlawreview.org/ 
Denno, D. W. (2014). Lethal injection chaos post-Baze. Georgetown Law Journal, 102(5), 13311382. Retrieved from http://georgetownlawjournal.org/

Dieter, R. C. (2008). Methods of execution and their effect on the use of the death penalty in the United States. Fordham Urban Law Journal, 35(4), 789-816. Retrieved from http://ir.lawnet.fordham.edu/ulj/

DiStanislao, P. T., III (2015). A shot in the dark: Why Virginia should adopt the firing squad as its primary method of execution. University of Richmond Law Review, 49(3), 779-809. Retrieved from http://lawreview.richmond.edu/

Enmund v. Florida, 458 U.S. 782 (1982).

Europe's moral stand has U.S. states running out of execution drugs, complicating capital punishment. (2014, February 18). CBS News. Retrieved from http://www.cbsnews.com/

Fan, M. D. (2015). The supply-side attack on lethal injection and the rise of execution secrecy. Boston University Law Review, 95(2), 427-460. Retrieved from http://www.bu.edu/bulawreview/

Furman v. Georgia, 408 U.S. 238 (1972).

Glossip v. Gross, 576 U.S. --- (2015).

Goldberg, R. C. (2015, May 4). Safe and effective for human executions? Glossip v. Gross and the Eighth Amendment bar against off-label drug lethal injection. Stanford Law Review, 68, 1-8. Retrieved from http://www.stanfordlawreview.org/online

Goldfarb, P. (2015, July 3). Response, Glossip v. Gross: Gross imagery: Fracturing legally over injecting legally. George Washington Law Review Docket. Retrieved from http://www.gwlr.org/glossip-v-gross/ 
Goodwin, W. (2015, January 6). Botched lethal injection executions reignite death penalty debate. NPR. Retrieved from http://www.npr.org/

Grace, M. E. (2009). Baze v. Rees: Merging Eighth Amendment precedents into a new standard for method of execution challenges. Maryland Law Review, 68(2), 430-479. Retrieved from http://digitalcommons.law.umaryland.edu/mlr/

Gregg v. Georgia, 428 U.S. 153 (1976).

Harding, R. M. (1996). The gallows to the gurney: Analyzing the (un)constitutionality of the methods of execution. Public Interest Law Journal, 6, 153-178. Retrieved from http://www.bu.edu/law/central/jd/organizations/journals/pilj/

In re Kemmler, 136 U.S. 436 (1890).

Kennedy v. Louisiana, 554 U.S. 407 (2008).

Louisiana ex rel. Francis v. Resweber, 329 U.S. 459 (1947).

Malik, S. C., \& Holdsworth, D. P. (2015). A survey of the history of the death penalty in the United States. University of Richmond Law Review, 49(3), 693-710. Retrieved from http://lawreview.richmond.edu/

Nugent, P. R. (1993). Pulling the plug on the electric chair: The unconstitutionality of electrocution, William \& Mary Bill of Rights Journal, 2(1), 185-203. Retrieved from http://scholarship.law.wm.edu/wmborj/

Radin, M. J. (1978). The jurisprudence of death: Evolving standards for the cruel and unusual punishments clause. University of Pennsylvania Law Review, 126(5), 989-1064. Retrieved from https://www.pennlawreview.com/ 
Raeker-Jordan, S. (2011). Kennedy, Kennedy, and the Eighth Amendment: "Still in search of a unifying principle"? University of Pittsburgh Law Review, 73(1), 107-160. Retrieved from http://lawreview.law.pitt.edu/ojs/index.php/lawreview/index

Roberts v. Louisiana, 428 U.S. 325 (1976).

Roper v. Simmons, 543 U.S. 551 (2005).

Roy, P. (2002). Not so shocking: The death of the electric chair in Georgia at the hands of the Georgia Supreme Court in Dawson v. State. Mercer Law Review, 53(4), 1695-1716. Retrieved from https://law.mercer.edu/academics/journals/lawreview/

Sack, E. (2015, February 24). More death penalty puzzles highlighted by new Supreme Court case [Blog post]. Retrieved from http://law.rwu.edu/blog/more-death-penalty-puzzleshighlighted-new-supreme-court-case

Sanburn, J. (2013, August 7). The hidden hand squeezing Texas' supply of execution drugs. Time. Retrieved from http://www.time.com

Smith, S. F. (2015). Has the "machinery of death" become a clunker? University of Richmond Law Review, 49(3), 845-871. Retrieved from http://lawreview.richmond.edu/ Stacy, T. (2005). Cleaning up the Eighth Amendment mess. William \& Mary Bill of Rights Journal, 14(2), 475-553. Retrieved from http://scholarship.law.wm.edu/wmborj/

Stern, J. E. (2015, June). The cruel and unusual execution of Clayton Lockett: The untold story of Oklahoma's botched lethal injection - and America's intensifying fight over the death penalty. The Atlantic. Retrieved from http://www.theatlantic.com/

Stinneford, J. F. (2011). Rethinking proportionality under the cruel and unusual punishments clause. Virginia Law Review, 97(4), 899-978. Retrieved from http://www.virginialawreview.org/ 
Trop v. Dulles, 356 U.S. 86 (1958).

Weems v. United States, 217 U.S. 349 (1910).

Wilkerson v. Utah, 99 U.S. 130 (1878).

Woodson v. North Carolina, 428 U.S. 280 (1976).

Yehuda, J. (2013). Tinkering with the machinery of death: Lethal injection, procedure, and the retention of capital punishment in the United States. New York University Law Review, 88(6), 2319-2352. Retrieved from http://www.nyulawreview.org/

\section{Author Biography}

Brenda I. Rowe, JD, PhD, is an Assistant Professor of Criminology at Texas A\&M University San Antonio. Her research interests include legal issues in criminal justice, criminal justice legislation, and police-prosecutor relationships. 